fact that they can be influenced by changing the external factors acting on them: when external control factors are maintained constant, you can take them into account in the equations, setting the corresponding parameters. Didactic systems are characterized by structural instability and the presence of correlations, although until recently they have been considered mainly as functional systems, and synergetics provides a methodological basis for understanding the development of the educational system, explains the causes of crises, reliable forecasts and more. It has been substantiated that the use of ideas of synergetics in didactics is one of the possible directions to develop its theoretical bases, in particular, the combination of ideas of integration and synergetics gives the chance to develop qualitatively new directions of theoretical and experimental researches in didactics. The creative approach treats creative potential as the essence, the content of human nature. Pedagogical forecasts should be consistent with forecasts in other areas. It has been proved that only with a systematic, integrated approach it is possible to build real models and expect to obtain reliable and continuous multifaceted forecasting information needed to optimize solutions. Synchronization on the basis of integration of educational, educational and scientific processes in the educational institution and their coordinated interaction ensure the self-sufficiency of each process in terms of their self-similarity, which requires the use of a fractal approach.

Key words: integration, integration process, modeling, methodological approach, system approach, synergetic approach, creative approach, problem approach, fractal approach, prognostic approach.

Дата надходження статті: 07.052021 p. Рецензент: доктор педагогічних наук, професор Дутка Г. Я.

УДК 378.147

DOI https://doi.org/10.37915/pa.vi49.246

Рускуліс А. В. *,

orcid.org/0000-0003-2293-5715

Механцева В. М. *,

orcid.org/0000-0002-1728-0286

\title{
ФОРМУВАННЯ ЛЕКСИЧНОЇ КОМПЕТЕНТНОСТІ УЧНІВ 10-11 КЛАСІВ (ПРОФІЛЬНИЙ РІВЕНЬ)
}

У статті з'ясовано, щзо одне з магістральних значень в шкільному курсі мови мае вивчення лексичного рівня української мови; наголошено, що формування лексичної компетентності відбувається в системно-інтегративних зв'язках лексики з фонетикою, граматикою, орфографією та стилістикою, бо слово є явищем багатогранним; успінне засвоєння лексичного рівня української мови залежить від урахування специифічних підходів, принципів, закономірностей навчання та добору методів і прийомів навчання; потрактовано поняття «лексична компетентність» у розвідках науковців та визначено иї як високий рівень засвоєння лексичного рівня украйнської мови, уміння володіти лексичними засобами відповідно до ситуації мовлення, беззаперечне дотримання лексичних норм, оволодіння словниковим запасом украйнської мови, повага до украӥнського слова, активне використання власне украйнської лексики; простудійовано основні положення програми з украйнської мови для учнів 10-11 класів (профільний рівень), у якій за пріоритетне визначено формування лінгвокультурологічної, соціолінгвістичної компетентностей, що сприятиме формуванню лексичної компетентності сучасного учня шляхом усвідомлення ним мови як національного феномену; схарактеризовано домінантні завдання лінгвістичної (мовної) та соціокультурної змістових ліній; проаналізовано класифікацію лексичних вправ, до яких уналежнено: власне

*(C) Pускуліс А. B.

*(C) Механцева В. М.

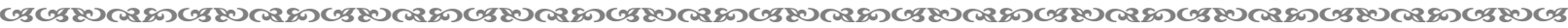


лексичні, що спрямовані на закріплення лексичних понять і формування вмінь тлумачити значення слова; лексико-граматичні вправи сприяють виявленню й установленню зв'язків між лексикою й граматикою, формуванню вмінь розрізняти лексичне й граматичне значення слова; лексико-орфографічні вправи забезпечують засвоєння й повторення особливостей написання слів та їхніх частин; лексико-стилістичні вправи забезпечують вироблення вмінь $і$ навичок правильного відбору і вживання слів у мовленні відповідно до характеру й мети висловлювання; наведено приклади таких вправ $і$ завдань до них, що передбачають аналіз слів-символів, вербалізацію концептів, вибудовування лексико-семантичного поля, обов'язковий інформаційнокомунікаційний супровід їx.

Ключові слова: лексична компетентність, лінгвістична й соціокультурна змістові лінї програми, система вправ, власне лексичні, лексико-граматичні, лексико-орфографічні, лексикостилістичні вправи, інформаційно-комунікаційний супровід вправ.

Постановка проблеми. Роль вивчення лексики в шкільному курсі мови має одне 3 магістральних значень. Аналіз наукових розвідок переконує, що рівень овододіння лексичним пластом мови визначає розвиток мовленнєвих умінь старшокласника. Звідси, основне завдання в процесі підготовки учнів 10-11 класів - застосування набутих знань у практичній діяльності, оволодіння активним словниковим запасом й розвиток умінь вільно оперувати ним відповідно до конкретно мовленнєвої ситуації. Слід нагодосити також, що формування дексичної компетентності відбувається в системно-інтегративних зв'язках лексики з фонетикою, граматикою, орфографією та стилістикою, бо слово є явищем багатогранним. Успішне засвоєння лексичного рівня української мови залежить від урахування специфічних підходів, принципів, закономірностей навчання та добору методів і прийомів навчання.

Аналіз досліджень. Дінгвістичні основи лексики - слово як предмет вивчення у зв'язках з іншими словами, системні відношення в лексиці тощо - всебічно досліджено в наукових студіюваннях мовознавців (І. Білодід, О. Бондар, В. Виноградов, А. Грищенко, А. Мацько, М. Микитин-Друженець, М. Плющ, О. Селіванова, Ю. Карпенко та ін.). Лінгводидактичні основи (специфічні підходи, закономірності, принципи, методи і прийоми) засвоєння лексичного рівня української мови й, відповідно, формування лексичної компетентності, репрезентовано в розвідках С. Карамана, О. Кучерук, I. Нагрибельної, В. Новосьолової, С. Омельчука, М. Пентилюк, Н. Сіранчук, В. Тихоші, I. Хом'яка та ін.

Мета статті - 3'ясувати сутність поняття «лексична компетентність» у сучасній лінгводидактиці, проаналізувати діючу програму з української мови для 10-11 класів (профільний рівень) із метою визначення пріоритетних напрямів засвоєння лексики; запропонувати систему вправ із вивчення лексики.

Викдад основного матеріалу. Гдибокий аналіз наукових джерел демонструе, що вчені прагнуть 3'ясувати особливості поняття «лексична компетентність» на усіх ланках шкільної освіти. Зокрема, Н. Сіранчук із проспекцією на мовну підготовку учнів початкової школи з'ясовує, що це «здатність особистості швидко і якісно, на рівні програми оперувати не словами, а семантичними полями, зі складу яких дюдина обирає потрібне слово, словосполучення, щоб із можливою точністю висловити свою думку в мовленні, спілкуванні, 3 опорою на граматичну структуру мови (макроструктуру мови)» [4, с. 40]. Нам імпонує думка В. Новосьолової, яка вкдадає в це поняття овододіння «дексичними засобами мови й умінні користуватися ними $<\ldots$. , передбачає багатий словниковий запас; правидьне вживання слова відповідно до поняття, що це слово виражає; ураховує можливості лексичної сполучуваності слів» [2, с. 12]. Повністю погоджуємося 3 О. Кучерук, що це інтегративне особистісне утворення (синтез релевантних знань, умінь, ставлень, досвіду та ін.), «що дає змогу застосовувати лексичні знання в навчально-мовній практиці, у різних видах мовленнєвої діяльності й ситуативно виправдано користуватися дексичними засобами під час спілкування в умовах соціальної os 
комунікації» [1]. Отже, узагальнивши студіювання науковців, переконуємося, що лексична компетентність - це високий рівень засвоєння лексичного рівня української мови, вміння володіти лексичними засобами відповідно до ситуації мовлення, беззаперечне дотримання лексичних норм, оволодіння словниковим запасом української мови, повага до українського слова, використання власне української лексики.

Із метою формування лексичної компетентності старшокласника звертаємося до основних положень програми з української мови для учнів 10-11 класів (профільний рівень), мета якої «полягає у формуванні інтелектуально розвиненої, морально досконалої, національно свідомої, духовно багатої мовної особистості, яка вільно володіє виражальними засобами сучасної української дітературної мови, іiі стилями, різновидами, жанрами в усіх видах мовленневої діяльності (аудіювання, читання, говоріння, письмо), відзначається активною громадською позицією, готовністю до подальшого професійно орієнтованого навчання, спроможна самостійно визначати цілі самонавчання, самовиховання й саморозвитку та дієво їх реалізовувати» [5], а магістральним завданням визначено виховання патріота Української держави, формування його національної ідентичності; формування лінгвокультурознавчої компетентності, що забезпечує розуміння самобутності української мовної картини світу, знання констант національної культури, концептуальних лінгвокультурем, готовність до міжкультурного діалогу, сприймання мови як мистецького явища шляхом вивчення творів мистецтва [там само].

Авторський колектив програми (Д. Мацько, Т. Груба, О. Семеног, Т. Симоненко) за пріоритетне визначає формування дінгвокультурологічної, соціолінгвістичної компетентностей, «зокрема дінгвістичним маркерам соціальних стосунків, етномовним культурним універсаліям, мовним етичним формулам, стилям, підстилям і профільним мовним жанрам, що сформувалися на профільній інформації, іiі понятійному змісті і каналах передачі» [там само], що сприятиме формуванню лексичної компетентності сучасного учня шляхом усвідомлення ним мови як національного феномену.

Суть процесу навчання української мови в 10-11 класах визначають змістові лінії (дінгвістична, мовна, мовленнєва (комунікативна), соціокультурна діяльнісна (стратегічна)). Зокрема, мовна, дінгвістична змістова лінія передбачає ознайомлення з історією української мови та новітніми напрямами сучасної дінгвістики (соціолінгвістика, етнолінгвістика та дінгвокультурологія, комунікативна дінгвістика), риторики. Учні засвоюють поняття «лінгвокультурема», «етнографізми», «ономастика» та ін., з'ясовують багатство діалектної лексики. Особливу увагу звернуто на дослідження архаїзмів та історизмів, які уможливлюють відтворення культури народу; власне української фразеології, просторічної лексики, молодіжного сленгу, екзотизмів та пуризмів, проблеми мовної інтерференції. На нашу думку, формування лексичної компетентності умождивдюється шляхом виконання низки завдань, передбачених соціокультурною змістовою лінією, в межах якої запропоновано для розгляду такі проблеми: «Мовна особистість крізь призму української родини», «Етноестетика української мови»; «Етносимводіка слів батько, мати, син, донька, дід, баба, сестра, брат» (10 клас); «Слово як носій добра, істини й краси», «Українська мовоментальність», «Мовосимволи української державності», «Концепти милосердя, захисник, гідність, честь, свобода в українській літературі, у масмедіа», «Мовосимволи майдан, євромайдан», «Мова - носій культури народу-мовотворця» та ін. (11 клас). Підготовлені матеріали зреалізовуються на уроках мови шляхом ведення дискусій, проголошення доповідей, укладання словників і карт, розроблення проєктів, екскурсій, участі в конференціях, круглих столах, а в час змішаного навчання - під час вебфорумів, електронних екскурсій, у процесі укладання електронних словників (довідників), етнолінгвістичних альбомів. Аналіз навчальної програми «Українська мова. Профільний рівень» продемонстрував, що мовна (дінгвістична) й соціодінгвістична лінії передбачають низку завдань, які забезпечує успішне формування лексичної компетентності старшокласників.

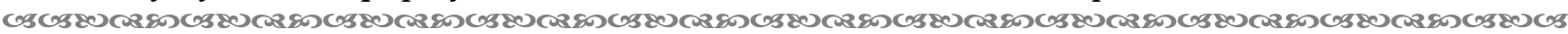
37 
Із метою формування лексичної компетентності старшокласника, ураховуючи основні положення програми з української мови для 10-11 класів (профільний рівень), спробуємо репрезентувати систему вправ. У дослідженні послуговуємося класифікацією вправ, запропонованою М. Пентилюк, яка виокремлює такі їхні види: власне лексичні, що спрямовані на закріплення лексичних понять і формування вмінь тлумачити значення слова; лексико-граматичні вправи сприяють виявленню й установленню зв'язків між лексикою й граматикою, формуванню вмінь розрізняти лексичне й граматичне значення слова; лексико-орфографічні вправи забезпечують засвоєння й повторення особливостей написання слів та їхніх частин; лексико-стилістичні вправи забезпечують вироблення вмінь і навичок правильного відбору й уживання слів у мовленні відповідно до характеру й мети висловлювання [3, с. 157-160]. Наведемо приклади вправ.

Власне лексичні вправи:

Вирава 1. Ознайомтеся з уривком тексту.

Ще зовсім малою була Настася, коли напали на Рогатин волохи. 3-поміж іншого було привезено також усе срібло і всі книги цінні з цеекви Святого Ауха, бо отецьь Аісовський пах'ятав усе так, що з його слів було споряджено папір, за яким волохи мали повернути крадене. А тал було три келихи позолочені, три білі, всього келихів вісім, а в них срібла шістнадиять гривень і п'ять півлута, а ще хрести, кадильниці, лампи, офіри різні - на сорок три гривні й тринадиялть лугів срібла. Опріч псалтир і часослов, тріодь цзвітна, октоїх та ще чотири книги, назв яких запам'ятати він не спроможе, бо великої мудрості книги (П. Загребельний).

1. Із якого твору запропонований уривок? Випишіть архаїзми та історизми. 3'ясуйте їхнє значення та доберіть сучасні відповідники. Запропонуйте ментадьну карту до теми «Дексикологія».

2. Назвіть головних героїв твору. Чи можна їхні імена уналежити до прецедентних? Обгрунтуйте. Які ще, на вашу думку, назви у творі доцільно віднести до прецедентних феноменів?

Для опрацювання учням запропоновано уривок із твору П. Загребельного «Роксолана», головними героями якого є Роксолана (Настя Лісовська) й Сулейман. Аналіз текстового матеріалу дозволить схарактеризувати пасивну (застарілу) лексику української мови, яка була в активному вжитку в XVI ст., що ознайомить старшокласників із тогочасною культурою українського народу.

Пексико-граматичні вправи:

Вирава 2. Прочитайте текст. Випишіть однокореневі слова, розташувавши послідовно в парах за ланцюговим зв' язком твірної основи. 3'ясуйте словотворчі афікси.

Відколи існуе людство на землі, відтоді воно дбае про продовження свого роду.

Рід. Рідня. Нація. Коли взяти в широкому розумінні иі слова, то родина - не лише близькі родичі, а й далекі. А родина до родини - народ. Ми з вами украйнський народ, який складаеться зродин малих і великих, дружніх і працьовитих. Отже, знаючи, зберігаючи й примножуючи свою родовідну пам'ять, знаєи зберігаєи і примножуеш пам'ять свого народу. "Родовідна пам'ять, - за В. Скуратівським, - явище у традиційному украйнському побуті унікальне. Очевидно, мало хто знае, щзо у давнину було за обов'язок знати поіменно свій рід від n'ятого і навіть до сьомого коліна. Старі села в Україні зросталися, кумувалися, ріднилися. Народини справжня подія, родинне свято, яке справляють урочисто: з хрестинами, щедрим гостюванням, ім'янареченням. У дитини з'являються хрещені батько й мати, а то й по двоє, по троє. Убатьків - куми. Зростае рідня. Аюди поріднилися, породичалися. Стае більщим рід міцьнішим нарід. Всі одного кореня. Спробуй такого знищити, вирубати, коли він проростає то там, то там, пускае нове пагіння» (О. Макаренко).

1. Випишіть дієслова, утворені а) суфіксально-постфіксальним і б) префіксальносуфіксально-постфіксальним способами.

2. Укладіть хмару слів, що характеризує лексему «родина».

Пексико-орфографічні вправи: 
Вирава 3. Прочитайте текст.

В одноверхому тридільному храмі з Рогатина, щя в Галичині, західний зруб (бабінець) і східний зруб (вівтар) накривали хатні дахи, які притикались до стінок баштоподібної нави, завершеної дахом наметового типу з двома заломами. На рівні першого поверху стіни захищав спеціальний звисаючий дах, щьо обійшов споруду з усіх боків, названий опасанням (Г. Онкович).

1. Дайте тлумачення словам, що означають частини споруд храму.

2. Поставте наголос у запропонованих словах. Розвиток, храм - одноверхий, дахом, тридільний, Рогатин, вівтар, баштоподібний. Перевірте правильність виконання завдання за QR-кодом:

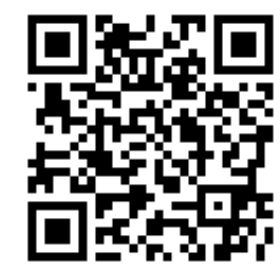

3. Зробіть розбір за будовою таких слів: споруда, розвиток, духовність, завершений, звисаючий, тридільний, притикатися, наметовий.

Окрім аналізу лексем, що означають частини будівлі храму, учні повторюють відомості з орфоепії (акцентологічні норми), будови слова, лексикології. Така вправа спрямована на залучення учнів до пошукової лексикографічної роботи.

Иексико-стилістичні вправи:

Вирава 4. Ознайомтеся 3 тестом.

\section{XATA}

Напишу я слово про хату за тисячу верст $і$ за тисячу літ від далеченних сивих давен аж до великого мого часу всесвітньо-атомної бомби. На Украӥні й поза Вкраӥною сущою. Білу, з теплою солом'яною стріхою, що поросла зеленим оксамитовим мохом, архітектурну праматір пристанища людського, незамкнену, вічно одкриту для стуку в двері, без «можна» i без «войдіте!» високонравственну людську оселю. Бідну і ясну, як добре слово, і просту, ніби створихи ії не робочі людські руки, а сама природа, немовби виросла вона, мов сироїжка в зеленій траві.

Опишу ӭ̈ внутрішній образ. Все, щзо в ній є й чого нема, й не було ніколи, хоч $і$ могло би бути. А не було й нема в ній безлічі речей. Нема в ній челяді, немае гайдуків, прислужництва нема. Немае кабінетів, віталень, спалень, де довго сплять, $і$ не було в ній розпусти $і$ лінощів паразитизму. Немае на стінах фамільних портретів, і скарбів нема в сундуках, і ковані панцииі предків не красуються по ї кутах, бо билися гаразд лицарі - дідки-небораки без панцирів зодверто голими руками. А потім погнили онучі, потрухли клейноди до нитки, не стало й сліду на землі. І вона оставалась там жити, і так чомусь ставалось на світі, щьо поза нею вона в'яне, як квітка на дорозі.

Опишу я покинуту хату. Споконвіку кидали ї̈, ї хто кидав, мало вертався. Носило його скрізь усіма вітрами, чи сам, мов собака, бігав усе життя за чужим возом, i, може, згадував ї, як щасливе дитинство, занедбану свою совість і мову занедбану свою. Покидав він у хаті свою мову.(О. Довженко).

1. Вербалізуйте концепт «хата» в запропонованому тексті. В яких творах, із вивчених на уроках української літератури, майстри слова описували батьківську хату?

2. Яке стилістичне навантаження в тексті має використання слова «чорногуз». Чи є це слово симводом українського народу? Думку обгрунтуйте. Доберіть до нього синоніми. Вибудуйте лексико-семантичне поле слова «лелека». Запропонуйте листівку «СовоНорма».

3. Яку роль виконують тропи, використані автором?

Тексти містять народознавчий матеріал про українське національне житло, як згусток традицій, обрядів та звичаїв. Не випадково наш вибір зупинився на уривку 
твору О. Довженка, слова якого звучать, як закдик не забувати й не відрікатися від рідної мови.

Висновки. Отже, одним із пріоритетних завдань сучасної школи є формування лексичної компетентності учня. Аналіз програми 3 української мови 10-11 класі (профільний рівень) дозволив нам з'ясувати особливості вивчення лексики. Спираючись на існуючу в лінгводидактиці класифікацію вправ (власне лексичні, лексико-граматичні, лексико-орфографічні та лексико-стилістичні) ми запропонували власне бачення добору текстового матеріалу й завдань до таких видів, що передбачають аналіз слів-символів, вербалізацію концептів, вибудовування лексико-семантичного поля. Обов'язковою вимогою до добору системи вправ був інформаційно-комунікаційний супровід їх; словникову роботу організовано 3 використанням QR-кодів, вкраплено завдання 3 медіатекстами; запропоновано створення ментальної карти, презентації, хмар слів, дистівки «СловоНорма», що також є актуальним в час упровадження змішаних форм роботи.

У подальших наукових дослідженнях плануємо розробити систему вправ, вибудовану на основі регіональних текстів.

\section{Список використаних джерел:}

1. Кучерук О. Формування лексичної компетентності учнів у процесі навчання української мови 3 використанням методу проектів. URL: http://eprints.zu.edu.ua.pdf

2. Новосьолова В. Особливості роботи з формування лексичної компетентності учнів основної школи на уроках української мови. Українська мова і література в школі. 2014. № 7. С. 12-19.

3. Пентилюк М. Система лексичних вправ - важливий засіб мовленнєвого розвитку учнів російськомовних шкіл. Актуальні проблеми сучасної лінгводидактики: зб.статей. К.: Ленвіт, 2011. С. $154-160$.

4. Сіранчук Н. До проблеми створення методичної системи формування лексичної компетентності учнів. Наукові записки Національного університету «Острозька академія», серія «Філологія», 2020. Вип. 9 (77). С. 303-306.

5. Українська мова. 10-11 класи. Програма для профільного навчання учнів загальноосвітніх навчальних закладів. URL: https://mon.gov.ua/ua/osvita/zagalna-serednya-osvita/navchalniprogrami/ navchalni-programi-dlya-10-11-klasiv

\section{References:}

1. Kucheruk, O. (2018). Formuvannia leksychnoi kompetentnosti uchniv u protsesi navchannia ukrainskoi movy $z$ vykorystanniam metodu proektiv [Formation of pupils' lexical competence in the process of learning the Ukrainian language using the project method]. Retrieved from http://eprints.zu.edu.ua.pdf [in Ukrainian].

2. Novosolova, V. (2014). Osoblyvosti roboty $\mathrm{z}$ formuvannia leksychnoi kompetentnosti uchniv osnovnoi shkoly na urokakh ukrainskoi movy [Features of work on the formation of primary school pupils' lexical competence in Ukrainian language lessons]. Ukrainska mova $i$ literatura $v$ shkoli, 7, 12-19 [in Ukrainian].

3. Pentyliuk, M. (2011). Systema leksychnykh vprav - vazhlyvyi zasib movlennievoho rozvytku uchniv rosiiskomovnykh shkil [The system of lexical exercises is an important means of speech development for pupils of Russian-language schools]. Aktualni problemy suchasnoi linhwodydaktyky, 154-160 [in Ukrainian].

4. Siranchuk, N. (2020). Do problemy stvorennia metodychnoi systemy formuvannia leksychnoi kompetentnosti uchniv [To the problem of creating a methodical system of formation of pupils' lexical competence]. Naukovi zapysky Natsionalnoho universytetu «Ostrozka akademiia», seriia «Filolohiia», 9 (77), 303-306 [in Ukrainian].

5. Ukrainska mova. 10-11 klasy. Prohrama dlia profilnoho navchannia uchniv zahalnoosvitnikh navchalnykh zakladiv [Ukrainian language. 10-11 forms. Educational program for subject-oriented instruction of secondary schools pupils]. Retrieved from https://mon.gov.ua/ua/osvita/zagalna-serednyaosvita/navchalni-programi/navchalni-programi-dlya-10-11-klasiv [in Ukrainian]. 
Ruskulis L. V., orcid.org/0000-0003-2293-5715

Mekhantseva V. M., orcid.org/0000-0002-1728-0286

\section{FORMING STUDENTS' LEXICAL COMPETENCE OF 10-11 FORMS (SUBJECT-ORIENTED INSTRUCTION LEVEL)}

It is found out in the article that one of the main places in the school language course is the study of the lexical level of the Ukrainian language. It is emphasized that the formation of lexical competence occurs in the system-integrative connections of vocabulary with phonetics, grammar, spelling and stylistics, because the word is a multifaceted phenomenon. Successful mastering of the lexical level of the Ukrainian language depends on taking into account specific approaches, principles, patterns of learning and selection of methods and techniques of teaching.

The concept of "lexical competence" in the research of scholars is interpreted and defined as a high level of learning the lexical level of the Ukrainian language, the ability to master lexical means in accordance with the situation of speech, unquestioning observance of lexical norms, mastering the vocabulary of the Ukrainian language, respect for the Ukrainian vocabulary, active use of the Ukrainian vocabulary.

The main provisions of the Ukrainian language program for students of 10-11 forms (subjectoriented instruction level) have been studied, in which the formation of linguocultural and sociolinguistic competences is prioritized, which will contribute to the formation of lexical competence of modern students by understanding the language as a national phenomenon. The dominant tasks of linguistic and socio-cultural semantic lines have been characterized.

The classification of lexical exercises has been analyzed. It is noted that lexical exercises include actually lexical exercises, which are aimed at consolidating lexical concepts and forming the ability to interpret the meaning of a word; lexico-grammatical exercises which help to identify and establish connections between vocabulary and grammar, form skills for distinguishing lexical and grammatical meaning of a word; lexical and orthographic exercises which provide mastering and repetition of spelling features of words and their parts; lexical and stylistic exercises which provide the development of skills and abilities of correct selection and use of words in speech in accordance with the nature and purpose of expression.

Examples of such exercises and tasks to them have been represented, which provide analysis of words-symbols, verbalization of concepts, construction of lexical-semantic field, obligatory information-communication support of them.

Key words: lexical competence, linguistic and socio-cultural semantic lines of the program, system of exercises, actual lexical, lexico-grammatical, lexical and orthographic, lexical and stylistic exercises, information-communication support of exercises.

Дата надходження статmі: 30.04.2021 p. Рецензент: доктор педагогічних наук, професор Трифонова О. С. 